\title{
SPEAKERS' EVALUATIONS OF THE ESTONIAN AND THE RUSSIAN LANGUAGES IN TALLINN. BETWEEN LINGUISTIC STABILITY AND INTERETHNIC TENSION
}

\author{
Josep Soler Carbonell \\ Universitat de Barcelona and University of California
}

\begin{abstract}
This article presents some preliminary results from fieldwork (observatory participation, in-depth interviews and focus-group discussions) conducted mainly in Tallinn both with Estonians and Russophones, i.e. it represents work in progress, as this data is currently under review. However, before going into the presentation and analysis of these results, I will set up the framework that will let us have a more specific idea about how to read the results, and also, I will give a description of the methodological tools I used to obtain the available data. Finally, at the end of the article, I shall close with the most relevant conclusions we can arrive at, while at the same time giving some suggestions for further inquiry.
\end{abstract}

Keywords: Estonian, Russian, linguistic ideologies, language values

\section{Theoretical framework: globalization and linguis- tic ideologies}

As a sociolinguist with an anthropological focus, I am interested in the study of cases with a certain degree of linguistic complexity. In those cases, it is believed that the ideas people have about languages (as linguistic or language ideologies have been traditionally understood - cf. Woolard 1998) play a crucial role in shaping its development, because, as Monica Heller puts it: "[o]ur ideas about language(s) are, in other words, not neutral; we believe what we believe for reasons which have to do with the many other ways in which we make sense of our world and make our way in it" (Heller 2008: 518). Linguistic ideologies, in this sense, are both a bridge for us to analyze the context at a macro-level and also a powerful constituent of it, acting from the more micro-level.

I believe this is an especially meaningful approach nowadays, in the era of Globalization. To my understanding, this proc- 
ess has come to put a lot more pressure on speakers' identities, which have an ideological base, and the result is that their linguistic ideologies or language representations are being challenged, in their more traditional sense. What is more interesting in our times, though, is that not only the so-called minority language speakers are being affected by this process, but also speakers whose language is geographically and demographically more spread, who have historically enjoyed a safer position: " $\mathrm{t}] \mathrm{h}$ ere is a widespread impression that local languages and identities are under threat of displacement, dissolution or death [...]. Globalization is often dubbed as the source of this sense of threat, which is not restricted to traditional territorial minorities, but to virtually all linguistic communities at least in the so-called Western world" (Pujolar 2009).

Therefore, I think we can quite safely argue that we are at a turning point in terms of linguistic diversity maintenance. In the early 1990s, there were the first most prominent calls for attention to the fact that, during the present century, the biggest part of the existing linguistic diversity would disappear, meaning that only a $10 \%$ of the languages that are still spoken nowadays had a foreseeable future through to the 22nd century.

Thinking in those terms, it would be necessary from our side to contribute to our science with research with the objective of better understanding the Globalization process, how it really affects linguistic landscapes, what is in it that threatens linguistic communities, if there is something, or on the contrary, if this process can help threatened linguistic communities somehow build stronger identity ties that help them establish a better future for themselves.

The idea here is for us to try and escape from the "great paradox" that Carme Junyent (1998) talks about, in the sense that all those mechanisms that have helped spread dominant languages, at the same time, have contributed to the decline of dominated ones. To her, the most worrying of all is that these mechanisms are linked to progress in the most positive meaning of the word. Why, she asks herself, is it so that, what is good for humanity is not so good for diversity, which at the same time, is good for humanity? In order to help us understand what she is talking about, she mentions some of these things specifically, such as the following examples: writing, schooling, the access of women to the labor market, and the enhancement of communications and movements. All sorts of things that could theoretically be useful for the maintenance of linguistic diversity and which, at the end of the day, end up being 
the pillars of language substitution. As I mentioned in the previous paragraph, one of the most important aims of sociolinguistic research should be to try to understand how the Globalization process works in order to avoid, as much as possible, making it one more of these elements and turn it into a truly positive sign of our progress as a species.

To me, there is one thing we can say that Globalization is doing, linguistically speaking: it is enhancing the value of languages as a resource in the terms described by Bourdieu: "[D]iscourses are not uniquely (or if they are so, it is only exceptionally) signs destined to be understood, deciphered; they are also signs of richness destined to be valued, appreciated and signs of authority destined to be believed and obeyed. [...] in everyday life, it is very rare that language functions only as a pure communication tool" (Bourdieu 1982: 40). The question for us, in my opinion, is to try and see how it is that languages are valued and granted authority, which languages are valued to do what and on what terms.

All in all, the whirlpool of our times, in linguistic terms, is captured by Bastardas in the following terms:

[W]e are maybe going towards a time of fears due to the rising level of the interrelation and contact, where there is need for dialogue and imagination in order to reorganize the human species from a linguistic and identity point of view. Probably, the consensus will have to stem from the fact that, in the face of the internationalization process of the economy and the contacts in general, it is necessary to recognize that people and companies might share a common language [English] (or more) for intercommunication. At the same time, we need to accept that many countries and human groups would not want that this "common language of intercommunication" replacing their own code in their normal and usual "internal" functions in each territory [...]. As can be seen, it all demands many changes also from the language policy and planning perspective, and it presents a huge task for the future. (Bastardas 2007: 39)

Finally, in order to tackle the study of situations with a certain degree of linguistic unrest, Kathryn Woolard's work on linguistic ideologies will be taken as a point of reference, specifically the anonymity and authenticity divide, which proves to be useful 
in capturing tensions derived from language confrontations. Just to provide a brief description of these ideologies to the unfamiliar reader, they can be summarized as follows:

[T] he ideology of Authenticity locates the value of a language in its relationship to a particular community. That which is authentic is viewed as the genuine expression of such a community, or of an essential Self. Within the logic of authenticity, a speech variety must be perceived as deeply rooted in social and geographic territory in order to have value. [...] When authenticity is the legitimating ideology of a language, the linguistically marked form is celebrated, and accent matters. [...]

In contrast to minoritized languages, hegemonic languages in modern society often rest their authority on a conception of anonymity. Anonymity is an ideological foundation of the political authority of the Habermasian bourgeois public sphere (Habermas 1989). [...] The disembodied, disinterested public, freed through rational discourse from the constraints of a socially specific perspective, supposedly achieves a superior "aperspectival objectivity" that has been called "a view from nowhere" (Nagel 1986). [...] (Please remember that I speak of ideologies rather than objective realities throughout this discussion.) [...] Anonymity is attributed not just to publics but also to public languages. [...] By this reasoning, public languages can represent and be used equally by everyone precisely because they belong to no-one-in-particular. They are positioned as universally open and available to all in a society, if only, as Michael Silverstein (1996) reminds us, we are good enough and smart enough to avail ourselves of them. [...] Sociolinguistic case studies have shown how an ideology of anonymity allows institutionally or demographically dominant languages to consolidate their position into one of hegemony." (Woolard 2008, emphasis added). 


\section{The study of linguistic ideologies in Estonia: setting and methodology}

This is how I have come to be interested in analyzing linguistic ideologies observed in Estonia: in order to see how speakers grant value to the languages in their context; to see the tensions or developments of such a situation of language contact; and to further compare it with another complex situation of language contact such as Catalonia. However, nothing will be mentioned about the results from fieldwork in Catalonia in this article. The idea here is to try and see to what extent the ideological divide outlined above fits into the analysis of linguistic ideologies in Estonia.

The main bulk of my fieldwork in Estonia was carried out in Tallinn. The main reason for this choice is that being the capital of the country, one can hypothesize that it will be there where a higher degree of mixture and heterogeneity can be observed. In fact, this is actually the case, as pointed out by Ülle Rannut (2002). Just by merely looking at the statistical figures of Tallinn's population, we can understand our claim better: out of the 398,594 inhabitants as of 01.01.2009, 219,900 were of Estonian ethnicity and 144,937 were Russian ${ }^{1}$. These are the two main communities in the city, which live in a rather segregated manner, something that provides the feeling that the two of them are rather isolated. In that sense, Estonian tends to be positively evaluated from an instrumental point of view, as a tool to be promoted socially and in the labor market. Generally speaking, there are few chances for ethnic Russians to generate positive attitudes towards Estonian language (Ülle Rannut 2002). We need to take all this into account throughout the article, as the main data for my study was obtained in Tallinn.

The methodological tools that were used are the following ones: participatory observation, focus-group discussions, in-depth interviews, and an ethnographic questionnaire. The participatory observation was carried out at a language school for adults situated in the city center of Tallinn. The activity that was observed there was the dynamics of interaction between the students of the language course I taught. Occasionally, I could also observe the same interactions from the students of another course that took place at

1 Data retrieved from the Statistics Estonia web page (www.stat.ee), consulted on 19.10.2009. 
the same time as the one I conducted. In my course, though, there were eight participants: four ethnic Estonians and four ethnic Russians.

As for the focus-group discussions, the sample used for the study was also gathered from the same language school. Two sessions of this kind of discussion were conducted: one with ethnic Estonians ( 7 participants) and one with Russophones (6 participants). In each case, the discussion was conducted in the group's language (in Estonian with the ethnic Estonians and in Russian with the ethnic Russians). The activity took place in the same language school: the participants were asked to stay longer after our class one day in order to carry out the discussion, and they agreed to do so. I used the "question-answer" approach to elicit their opinions on the topic of inquiry, but was not very strict on either the timing, or the order. It was my interest to have the sense of a flowing discussion than intervening in excess, and if I perceived that there was something specific that they wanted to comment on or in more detail, I would let them continue talking about it. The approximate length of both focus-group discussions was 40 minutes.

When it comes to the in-depth interviews, here it is the snowball sampling technique that was used in order to gather the interviewees: 17 in total, out of which 7 were ethnic Russians, 5 ethnic Estonians, and 2 from another ethnicity. The remaining 3 fall into a different category: what is called "cultural experts." For my study, this means that they had a special kind of relation with the analyzed topic (the sociolinguistic situation in Estonia): they were two university teachers and a Human Rights' NGO representative based in Tallinn. For the in-depth interviews, the same "question-answer" frame was used, with open-ended questions, trying to get the opinions of the interviewees on the topic of my interest. I was not strict about the timing here either, and therefore, I let my interviewees explain to me as much as they wanted in each question. This is why there are significant differences in the length of the interviews: some of them lasted just for 30 minutes or less, others were as long as several hours.

Finally, an ethnographic questionnaire was distributed among a representative sample of the students from the language school where I had previously conducted the participatory observation and the focus-group discussions. The main objective of this questionnaire was to obtain quantitatively complementary data for the 
previous qualitative work about language use and people's values, attitudes, and ideologies about languages. It has to be stressed, though, that the results from this questionnaire are just representative of the opinions of the students from that particular language school. The kind of questions I used for the questionnaire were mainly of a Likert scale type, where respondents had to alternatively mark their degree of acceptance of a given sentence, putting a tick on a five scale rank between "Totally agree" or "Totally disagree". The questionnaire was designed after Baker's (1992) model. The total number of the sample was $\mathrm{N}=142$, from which $\mathrm{N}=119$ declared to have Estonian as their first language and $\mathrm{N}=18$ Russian. 3 subjects reported to have been raised bilingually at home, so those questionnaires were discarded due to their low number and representation rate. It has to be also stated clearly from the start that the low number of Russian respondents might very well influence the results, as they will be presented in the following section. The reason that explains that low number here is that the school is considered to be an Estonian one; situated still in the City Center district, it is located on the way towards an Estonian outskirt of the town. Therefore, that lets us think that the majority of the students are Estonian, as it is the case in our sample too.

\section{Results}

In order for us to get a general overview, some of the results from the questionnaire will be presented first, and then we'll move on to the more qualitative data coming from the rest of the methodological tools described above. Let us have a look, first of all, at the language use among the studied sample. As we can see from Table 1, the two main ethnic groups appear clearly divided when the addressee belongs to a familiar context. When outside that frame, the "always Russian" side of the table becomes blurred towards the other side of the table.

This contrast and the tendency to use Estonian more than Russian outside a familiar context is emphasized in Table 2, where we see the percentage of language use by the studied samples in a series of given contexts. Finally, we provide one last table that shows more of the linguistic attitudes of both Estonians and Russians from our sample. In this part, they were asked to rank from 

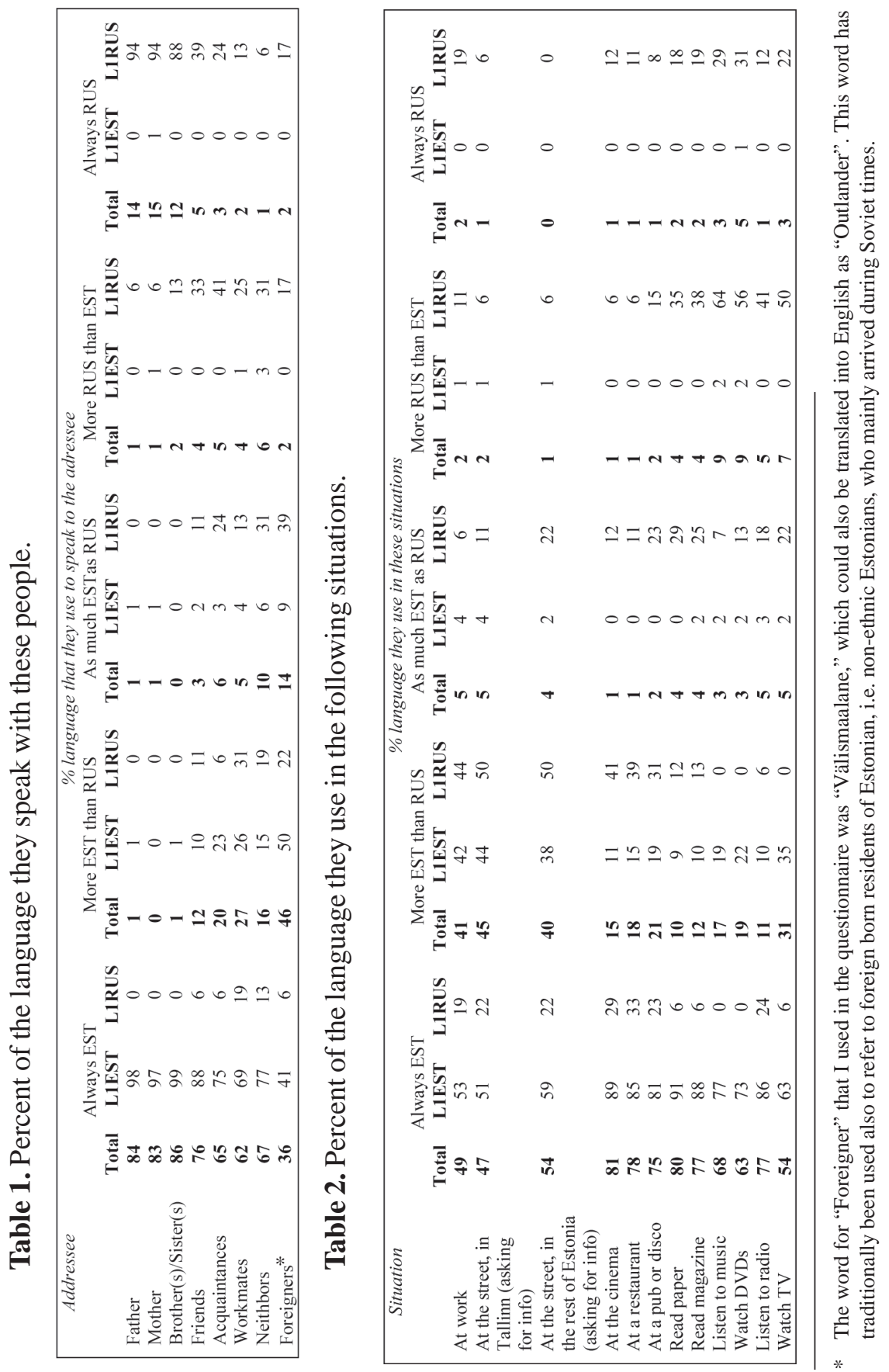
"very important", "not very important", "rather unimportant" and "not important at all" the value of Estonian in a series of activities, which were summarized under four headings: social activities (to make new friends, to be well perceived, to live in Estonia, to raise the children, to buy, to talk on the phone, to be accepted in society, to talk with friends, to talk with workmates and to talk with neighbors), work-related activities (to earn more money, to find a better job), activities related to the leisure time (to watch the TV, to watch DVDs, to sing, to do sport), and intellectual activities (to read, to write, to be more intelligent, to do exams). Each of the four values was graded from 100 ("very important") to 0 ("not important at all"). The final punctuation is the group's overall value that attributes to Estonian in each variable.

Table 3. The value of Estonian in social activities, work, leisure and intellectual activities.

\begin{tabular}{|lccc|}
\hline & Total & LIEST & L1RUS \\
$\begin{array}{l}\text { The value of Estonian in social activities } \\
\begin{array}{l}\text { The value of Estonian in work-related } \\
\text { activities }\end{array}\end{array}$ & $\mathbf{8 3}$ & $\mathbf{8 3}$ & $\mathbf{9 7}$ \\
$\begin{array}{l}\text { The value of Estonian in activities related to } \\
\text { the leisure time }\end{array}$ & $\mathbf{6 2}$ & $\mathbf{6 4}$ & $\mathbf{5 0}$ \\
$\begin{array}{l}\text { The value of Estonian in intellectual } \\
\text { activities }\end{array}$ & $\mathbf{8 9}$ & $\mathbf{9 0}$ & $\mathbf{8 2}$ \\
\hline
\end{tabular}

The first two tables give us the idea that Estonian is rather the unmarked language in Tallinn, the language that everybody uses by default, by both ethnic Estonians and ethnic Russians (at least among the sample under study here). Table number 3 above shows us that the Russophones that answered the questionnaire place a high or rather high value to Estonian in three of the four variables, although applying a T-test to measure statistically the differences among the two groups, there were indeed such differences by way of their L1, that is to say that the two groups are statistically distinct if we take their L1 as the comparative base. But in any case, what does have to be highlighted here is the rather high value with which they regard Estonian, especially for example if we take the work-related activities variable, where they significantly see it even more important than Estonians themselves. 
The trend that Russophones tend to use more Estonians from the start seems to be reinforced by the data collected from the interviews, especially considering the representatives of younger generations. See, for example, the following extract from an interview with a younger ethnic Russian speaker:

- QUEST: In what language do you start a conversation?

- JE1TQL1RUS: In Estonian. Many, many people speak Estonian in Estonia. Those who are Russian, they also know a bit Estonian, and those who are Estonian, they usually don't know Russian. Therefore, you speak in Estonian, and everyone will understand you. Then, it might be perceivable, if it' $d$ be better to use Russian. But in fact, you can usually see, who is Russian and who Estonian.

Or see also the following extract from another interview:

- QUEST: In formal situations, let's say for example at the doctor or at the bank, in what language do you speak?

- JE1EL1RUS: You start always in Estonian, and then you see, if the person that is attending you is Russian, you change, though it is even usual that it doesn't matter, you continue in Estonian.

- QUEST: Do you?

- JA1EL1RUS: Even if the other person is Russian, it doesn't matter, you speak in Estonian.

- QUEST: Even if he or she noticed that you are Russian, it's the same, you would go on in Estonian?

- JA1EL1RUS: Yes, it doesn't matter.

- JE1EL1RUS: For many of them it's already a principle. Those, who work at good companies, they hold to their positions and make an effort to keep speaking in Estonian with clients.

- JM1EL1BILING: It is also not comfortable to change all the time.

Therefore, it can be said that Estonian is being positively valued more than anything as a working language, a kind of tool for self-promotion especially in the labor market. This could also be retrieved from the interviews:

- QUEST: Do you think it's important to speak well Estonian?

- JE2TQL1RUS: In Estonia? Yes, I think it's important. It's 
difficult to find a good job without it, but it's simply the same whenever you don't speak the language that the majority of people speak. I know it personally that it you know Estonian very well, you have so many more opportunities. Not only opportunities, but the context around you expands, really, many more plusses.

As for the value ethnic Estonians grant to the Russian language, one can see a division of opinions in the following terms: it is either positively valued, as something which is good to know, that might open up a lot of opportunities (notice, therefore, that it is also granted value in economic terms), or it is something that, if you do not know, it does not really matter, and you should not really care about it. The following are several comments that are in line with the first trend as exposed here, collected as comments at the end of the questionnaires:

- "I think Russian is important, though I also think it should be everyone's free choice."

- "I find that teaching Russian is necessary in general education."

- "It's very good if Estonians know Russian, though I think Estonian children MUST NOT learn it necessarily."

- "It would be very necessary to have Russian as a second foreign language."

- "In order not to forget Russian, I listen and watch Russian programs. Knowing Russian is important, because it's a big language in the Estonian republic. It's also important to know other foreign languages: English, German, French, and Spanish."

However, as said above, there were also thoughts about the Russian language expressed in the following terms, in line with the second trend, just introduced now:

- "Russian is not very much important for me. I prefer rather English or Finnish. We are a small country and we rather learn foreign languages properly. Russians are from a big country and as a general rule, they think that all the world should speak Russian.”

The previous quote leads us to another interesting issue observed from our data: the role of English language in Estonia as a 
sort of lingua franca. Indeed, if there are people that prefer English to Russian, there will be instances when communication problems might arise. Moreover, the previous is likely to be true, especially if we take into account that there is a quite clear-cut division in society along language and age groups: as a general rule, younger ethnic Estonians do not speak Russian, whereas the elderly do; younger ethnic Russians do speak Estonian, the elderly do not. When doing fieldwork, during the participatory observation stage, I could personally see that sometimes, the intergroup language could be English, when neither the ethnic Estonians nor the ethnic Russians felt comfortable enough with the other's language. By using English this way, I argue, the split between the two groups might be still more considerable.

However, what makes me think that there is a perception that the Russian language might be something useful, valuable, and something good to know, is that from my data, I could also record speakers' opinions in the following terms. Next is a dialogue between three younger ethnic Russian speakers:

- JE1EL1RUS: Me, for example, I used to work at a hotel. When they saw that I spoke Russian, they hired me at once. A lot of people come from Russia, a lot of tourists. Intelligent people understand that it is a language you need. It proves that it's necessary for business, for objectives.

- QUEST: Is it something that still not many Estonians think, that Russian is a necessary language?

- JA1EL1RUS: We hope that there will be more people that think this way.

- JM1EBILING: No, it's true. I think that younger people already understand it this way.

To me, this shows us the advantageous position that bilinguals enjoy. Being able to use both languages alternatively, they are better prepared to take on better jobs, or at least, those that require being able to attend all customers regardless of the language they speak, which is something that, as pointed out before, tends to happen quite frequently in Tallinn. In order to further corroborate that claim, let's see the following quotation, this time from a conversation between two younger ethnic Estonian girls:

- JK2EL1EST: I went to a job interview and they asked me to talk in Russian and I was like "argh" [they laugh].

- QUEST: What interview was it, for what job? 
- JK2EL1EST: For [Name of a bank], a year ago. You need to know Russian to work here in Tartu. In Valga it's easier, there's a lot of people that think that in Valga there's plenty of Russians, but there's not so many of them, and usually they speak Estonian, with a strong accent, but they speak it. I have some Russian friends that speak Estonian very well. [...]

- JM2EL1EST: I think that younger people now have a different perception of the Russian language; they want to study it because they haven't had this "obligation".

Up to now, we have seen that the two linguistic communities might be at some point and mainly for economic reasons (in order to be better placed in the labor market) interested in knowing or having certain abilities in the other group's language. However, as it will further be shown, this kind of positive trend is cut down by other ideologies speakers of both ethnic groups hold. This other set of ideologies are usually loaded with historical resentment and tends to focus on the fact that it is the other group that is to blame for the rather bad present situation. See, for example, the following opinions, taken from the questionnaires:

- "Russians' integration has to work in the following direction: that they learn Estonian and try to take more part in the life in here."

- "It's important to consider Russian, even though any Russian speaker should integrate into Estonia. A non-Estonian, who has been born in Estonia, has to know the country's language, which is Estonian."

- "Estonian should remain the only official language of the Estonian republic, which everyone living here should speak at least at a conversation level. Russian language is a foreign language just like English, German, Finnish, etc. Any ability in foreign languages is useful."

At the same time, negative opinions about the Estonian language or language policies could be gathered from the interviews with ethnic Russian speakers, especially when talking about the progressive linguistic immersion program being implemented in Russian secondary schools:

- JT3TQL1RUS: I am against it. As a teacher, as a mum, I don't know, as a grandma. I think that a Russian kid, even not only Russian, but Spanish, German, etc. has to be edu- 
cated in his mother tongue. After that, he can already study other languages. So, to teach Russian kids, for example, geography in Estonian, I don't know.

Or see also the next extract from the focus-group discussion, along the same lines:

- JI3EMPL1RUS: So, there was a kind of Russification, as Estonians believe. And now you see, it has changed the other way round.

- QUEST: Estonianization.

- JI3EMPL1RUS: Yes, Estonianization, exactly, this is not normal at all.

At the beginning of the article, we asked if this particular division could be explained following Kathryn Woolard's ideology divide (Authenticity and Anonymity). In that sense, there are some instances from both groups that can lead us to think that there is something going on in that direction. For example, the following quotation, from an interview with an ethnic Estonian, is a clear example of the ideology of Authenticity:

- JA2BL1EST: We could say that we identify ourselves with this language. It's part of our identity, and that what else, that it's a language from the world, isn't it? Our small language and our small identity, it's a little bit another thing than the other big European or world identities. [...] It's yeah; it's an identity related question, isn't it? That in our present day world there is so much indifference, right? [...] It's this, our own small language, small our own culture, our society; they are like a little bit like they are not anonymous.

From the ethnic Russian side, though, the instances I could find that could more or less qualify as examples for the ideology of Anonymity were not so clear-cut. They certainly have a sense of universality, but it does not clearly go on the direction that Woolard proposes:

- JE1TQL1RUS : Yes, well, I like it because it's my mother tongue and also a big plus you have with Russian is that I can get any kind of information in my own language, that is, on any subject, on physics, technology, I can look up in the Internet for whatever there is. [...]. And 
also, when you travel abroad, there's always someone that speaks Russian, and he will help you or you'll be able to get close to one another because of that. And if you only know Estonian and English, then this is more difficult again, it's not that straightforward. So, I like it because it's widely used.

- QUEST: What do you like from your language?

- JKC1TNQL1RUS: Everything.

- JI2TQL1RUS: There's a lot of literature, on the Internet there's a lot of information.

- QUEST: Information, ah?

- JI2TQL1RUS: Yes.

- JKC1TNQL1RUS: Who controls the information, controls the world.

I can see, therefore, that this particular ideological division deserves to be addressed more specifically and therefore needs further analysis.

\section{Conclusions}

First of all, I think that the most relevant point is that there seem to be two opposite tendencies at work in the analyzed setting: on the one hand, it appears that each group might be interested in knowing the other group's language at some point, mainly for economic reasons. On the other, both of them have ideological constraints that prevent them from eventually doing so. This tells me, as I interpret it, that the Estonian society is feeling very much the contradiction that globalization is putting on plurilingual and complex societies like the Estonian one: the struggle between the two tendencies that multilingualism entails. It can be both a resource: a source for cultural and symbolic capital (a means to index identities) and ultimately, economical; and a problem: how do we deal with it, practically, at the political level, how to manage each groups demands for recognition with practical needs and particular historical backgrounds? These are not straightforward and easy to answer questions, and I think that the data presented here supports the view that we need to carefully consider the ideological, representational and cognitive-emotional level of the individuals in soci- 
ety, when coming up with language policies and planning. If we don't do so, we are missing a great deal of rich information so as to see how meaningful the policies that we are trying to implement will be, and therefore, we risk making them more inefficient than anything, i.e. making our efforts, however well-intended, useless.

It is my claim, too, that the increasing presence of the English language as a lingua franca might still bring about the division of the society. As it is already the world language, English is currently starting to have a more active role in Estonia as such, even if other studies conducted at a macro-level scale (see, for example, the Estonian Human Development Report 2008) show us that it is not yet the main tendency at all, but rather a mixture of Estonian and Russian is being used in interethnic exchanges. However, I don't think it is outrageous for us to start thinking about the possible consequences that the progressive use of English in Estonia as a lingua franca would have, and they might not be so much positive, I would say.

The situation is of course very complex, and as an outsider, I cannot pretend to say what is good and what is bad for the country. But I personally think that working towards the first tendency I have presented here, where there is a clear sense of complementarity and non-hierarchy, should be desirable. I am convinced (and I don't think I am the only one in that sense) that we need to work towards building up a sense of a shared common background, and working on a mutual understanding and empathy, where each group's frames of reference can coexist, is indeed a positive trend. I am now thinking not only in terms of Estonia, but taking a more general perspective, worldwide, that would be the ideal for us to work towards, unless we want to foster linguistic diversity decay. In that sense, Estonia has a chance to stand as an example for linguistic sustainability and interethnic peace, under one condition, however: that its people want to be such an example, for which their linguistic ideologies and mental representations should move in the direction I just proposed.

\section{Acknowledgements}

The fieldwork presented in this article was conducted thanks to the research studentships awarded by the City Council of Torelló, Catalonia (Spain) (Studentship "Segimon Serrallonga" 2008) and 
by the Estonian Institute (Studentship "Estophilus" 2009). The processing of these data and the bibliographical revision that have also made this article possible have benefited from two other studentships: the "'la Caixa' Foundation Fellowship, USA program 2008" and the "BE-DGR 2009" by the Catalan Government research agency AGAUR. My deepest gratitude to all these institutions for their support. Although the visions and ideas expressed here, with all their limitations, errors and shortcomings, reflect only those of the author, many professors and colleagues have influenced me greatly in that sense. In their representation, I would like to mention and give special thanks to Kathryn A. Woolard and Mart Rannut, as the reviewer of this article, for their helpful comments and critical readings of it. Many thanks also to Delaney M. Skerrett for his orthographical and editing revision.

\section{Address:}

Josep Soler Carbonell

Department of Anthropology

UCSD

9500 Gilman Drive

La Jolla (San Diego)

CA 92093-0532, USA

E-mail: jscarbonell@gmail.com

\section{References}

Baker, Colin (1992) Attitudes and language. Clevedon: Multilingual Matters.

Bastardas i Boada, Albert (2007) Les polítiques de la llengua i la identitat a l'era "glocal". [The politics of the language and identity in the "glocal" era.] Barcelona: Generalitat de Catalunya, Departament d'Interior, Relacions Institucionals i Participació. Institut d'Estudis Autonòmics (IEA) Barcelona.

Bourdieu, Pierre (1982) Ce que parler veut dire. Paris: Fayard.

Bourdieu, Pierre (1991) Language and symbolic power. Cambridge: Polity Press.

Crystal, David (2003) English as a global language. 2nd ed. Cambridge: Cambridge University Press.

Heller, Monica (2008) "Language and the nation-state: challenges to sociolinguistic theory and practice". Journal of Sociolinguistics 12, 4, 504-524.

Hogan-Brun, Gabrielle et al. (2007) "Language politics and practices in the Baltic states". Current Issues in Language Planning 8, 4, 469-631. 
Junyent, Maria Carme (1998) Contra la planificació. [Against planning.] Barcelona: Empúries.

LeCompte, Margaret Diane and Jean J. Schensul (1999) Designing and conducting ethnographic research. (Ethnographer's Toolkit.) Walnut Creek, CA: AltaMira Press.

LeCompte, Margaret Diane and Jean J. Schensul (1999) Analyzing and interpreting ethnographic data. (Ethnographer's Toolkit.) Walnut Creek, CA: AltaMira Press.

Pujolar, Joan (2009) "Language and identity in the globalized new economy: exploring sociolinguistic change". Conference presented in Tallinn, April 24, 2009 in the frame of the colloquium Barcelona vs. Tallinn: comparing language planning and policies.

Rannut, Mart (2004) “Language policy in Estonia”. Noves SL, Revista de Sociolingüística Spring-summer. http://www6.gencat.net/llengcat/noves/ hm04primavera-estiu/rannut1_6.htm

Rannut, Ülle (2002) Keelekeskkonna mõju muukeelsete õpilaste integratsioonile. Keel ja Kirjandus (Tallinn) 5, 342-358.

Schensul, Stephen L., Jean J. Schensul, and Margaret D. LeCompte (1999) Essential ethnographic methods: observations, interviews and questionnaires. (Ethnographer's Toolkit.) Walnut Creek, CA: AltaMira Press.

Schensul, Jean J., Margaret D. LeCompte, Bonnie K. Nastasi, and Stephen P. Borgatti (1999) Enhanced ethnographic methods: Audiovisual Techniques, Focused Group Interviews and Elicitation Techniques. (Ethnographer's Toolkit.) Walnut Creek, CA: AltaMira Press.

Vihalemm, Triin, ed. (2009) Estonian human development report 2008, 87-90. Tallinn: Eesti Koostöö Kogu.

Verschik, Anna (2005) "The language situation in Estonia". Journal of Baltic Studies 36, 3, 283-316.

Woolard, Kathryn A. (2008a) “Les ideologies lingüístiques: una visió general d'un camp des de l'antropologia lingüística”. [Linguistic ideologies: a general view of a field from linguistics anthropology.] Revista de Llengua i Dret 49, 179-199.

Woolard, Kathryn A. (2008b) "Language and identity choice in Catalonia: the interplay of contrasting ideologies of linguistic authority". In Kirsten Süselbeck, Ulrike Mühlschlegel, and Peter Mason, eds. Lengua, nación e identidad. La regulación del plurilingüismo en España y en América Latina, 303-323. Frankfurt am Main: Vervuert. Madrid: Iberoamericana. 
Kokkuvõte. Josep Soler Carbonell: Rääkijate hinnangud eesti ja vene keelele Tallinnas. Keelelise stabiilsuse ja rahvustevahelise pinge vahel. Käesolev artikkel esitleb esialgseid tulemusi välitöödest (osalusvaatlus, süvaintervjuud ja rühmaarutelud), mis on läbi viidud peamiselt Tallinnas nii eestlaste kui ka venelastega. Niisiis esitletakse jätkuva uurimuse tulemusi. Enne tulemuste esitlemist ja analüüsi on antud ülevaade raamistikust, mis näitab, kuidas tulemusi tõlgendada. Peale selle on kirjeldatud ka metodoloogilisi vahendeid, mida kasutasin olemasolevate andmete saamiseks. Artikli lõpetavad kõige olulisemad järeldused ja soovitused edasiseks uurimiseks.

Märksõnad: eesti keel, vene keel, keeleideoloogia, keelehinnangud 
